\title{
Period Films in the Postmodern or the "Enjoy!" Era
}

\author{
An, Sihwan*
}

The Treacherous is a film based on “ch'aehong (採紅, chaehong)," a historical affair through which ten thousand women of beauty were taken into the palace in the eleventh year of the reign of Yornsan'gun (Yeonsangun) in Chosŏn (Joseon) Korea. Numerous women from the scholar-official class to the lowest class, as well as married women, were brought to the palace. These women were called "unp'yŏng (unpyeong)." The Annals of the Choson Dynasty contains records of the appointment of Yim Sung-jae and Yim Sa-hong as ch'aehongsa (chaehongsa), responsible for the whole process of ch'aehong. Director Min Kyu-dong added cinematic imagination to these records and painted a picture of the "era in which people could not live without going insane." Yŏnsan'gun (played by Kim Kang-wu) begins to go insane upon learning the tragic truth about his mother, who was sentenced to death by poison. Only treacherous court officials surround him, telling him that they will give him the pleasure of a thousand years in just one day. Two of the most treacherous officials, Yim Sa-hong (played by Chŏn Ho-jin) and Yim Sung-jae (played by Chu Chi-hun) are father and son, who are trying to establish their positions through ch'aehong. In these efforts, they teach Tan-hŭi (played by Lim Chi-yŏn), a woman of exceptional beauty and talent, the techniques and skills to seduce the king. Meanwhile, Chang Nok-su (played by Ch'a Chi-yŏn), Yŏnsan'gun's concubine, can no

* Ph.D. Department of Drama and Cinema, Dongkuk University 
longer condone the acts and ambition of the Yims, and she also personally begins to train Sŏljungmae, one of the most celebrated kisaeng (female entertainers) of the time, to entice the king as well. Eventually, ch 'aehong becomes perverted into a power struggle in this era of insanity, and the palace turns into a site of bloodbath. Furthermore, as Yim Sung-jae develops romantic feelings for Tan-hŭi, who took part in ch'aehong to kill Yŏnsan'gun, the film begins to unfold riveting scenes of desire.

No matter the efforts to stay faithful to the historical truth, period films have no choice but to rely on cinematic imagination. In the same way, no matter the efforts to demonstrate cinematic imagination, it is impossible for period films to take a leap beyond the "fixed" historical truth. As a result, critical approaches to period films stand at the mouth of forking paths: historical truth and cinematic imagination. While historical truth is for historians to focus on, cinematic imagination is left up to film critics. Various characteristics of period films produced since the 2000 s are condensed in the Treacherous, which provides sufficient evidences to understand the cultural conditions that gave birth to the "historical imagination" of period films in the 2000s. Historical truth belongs to the past, but historical imagination arises from social and cultural conditions of the present. This article focuses on the "mouth of the present" that describes the reenacted past, rather than the reenacted past itself. Therefore, this paper is both a question - In what way are we trying to imagine the past in the flow of the "postmodern" era? - as well as an answer to the question.

\section{The "Naked Emperor" Standing on Shaking Ground}

Surrounded by treacherous court officials, Yŏnsan'gun is unable to see the world. His eyes are full of extreme agitation and anxiety, and he only lusts after women's naked bodies. Yŏnsan and women's naked bodies were conventional elements of films about Yŏnsan. However, when we locate such image of Yŏnsan in the stream of period films in the 2000s, 
we can find significance beyond conventionality.

Most period films from the 2000s feature kings as main characters. In period films from King and the Clown (Lee Chun-ik, 2005), Forbidden Quest (Kim Dae-woo, 2006), A Frozen Flower (Yu Ha, 2008), The Concubine (Kim Tae-sŭng, 2012), Masquerade (Ch'u Ch'ang-min, 2012), The Face Reader (Han Chae-rim, 2013), and The Royal Tailor (Lee Wonsŏk, 2014), to The Fatal Encounter (Lee Chae-gyu, 2014), cameras explore the king's residence, palace. In these films, the king undergoes sexual identity crisis as he falls in love with a man, gradually goes insane surrounded by women, or becomes utterly confused amidst power struggles that threaten his position. To the kings in the period films from the 2000s, the weight of the crown is too difficult to bear, as can be seen in one scene in the Treacherous, where Yŏnsan suckles on Chang Noksu's breast for consolation as if he had suddenly become an infant. Then how was the image of a king who stands precariously on shaking ground imagined? In other words, what are the cultural and social motives that paint the picture of an extremely disturbed and distressed king?

Since Jean-Francois Lyotard's The Postmodern Condition, we point to the "end of metanarratives" as a characteristic of postmodern society. ${ }^{1}$ The end of metanarratives gave birth to the outlook of a society that pursues values of differences and diversity, which had been oppressed by metanarratives. Historical studies also cannot avoid the influence of postmodernism, and there probably is no need to explain in depth the flow of postmodern historical studies. But it is important to point out that a new trend arose with the emergence of the postmodern historical studies: film critics began to focus on period films from a different point of view than as "reenactments of facts." This trend of film criticism emphasized the possibility of period films to proactively produce new understandings of history by revealing microhistory of individuals, which had been excluded from grand discourses in the past, as well as by parodying and

1 Jean-Francois Lyotard, trans. Yu Chŏng-wan, Posŭtŭ modŏn-ŭi chokŏn (The Postmodern Condition), (Minumsa, 1999). 
commenting on history. In particular, postmodern historians such as Hayden White, Natalie Davies, and Robert A. Rosenstone provided the ideological basis to find subversive values in period films. From this perspective, the scene where Tan-hŭi, who represents the public, castigates Yŏnsan in the Treacherous, saying "Be a human even if you cannot be a king," can be assessed as a way of looking at and commenting on history from the bottom up.

However, did the emergence of postmodernism only bring about positive values such as the pursuit of differences and diversity that had been oppressed until then? The trend of film criticism based on postmodern historical studies turned a blind eye to another aspect of postmodernism - the fact that postmodernism took away the firm foundation on which we can rely. As Slavoj Zizek pointed out, the advent of the postmodern era brought about the destruction of the symbolic order, which had supported the society through social institution, law, and custom. $^{2}$ Zizek explained this situation figuratively through Hans Anderson's tale, "The Emperor's New Clothes." What kind of situation resulted from the child's revelation that the emperor is not wearing anything at all (end of metanarratives)? The child's revelation did not bring about a desirable result of stripping hypocrisy from the society, but rather the worst situation of societal dissolution. When metanarratives are destroyed, from whom can we receive the approval of our identity? By granting identicalness to the decentered human existence, the symbolic order guaranteed a stable identity for humans. However, in the era, in

2 Slavoj Zizek, trans. Pak Chŏng-su, Kŭdŭ-rŭn jagiga ha-nŭn i-rŭl alji mot'anaida (For They Do Not Know What They Do), (Ingan sarang, 2004), p. 159.

However, Zizek's concern in this matter does not mean he unconditionally supports the symbolic order. He demands people to look at the impossibility of integration or consistency of the symbolic order. The society has always been divided and will stay divided in the future. The issue is in the fact that we do not acknowledge such negativity of the symbolic order. In other words, Zizek asserts that we must stop concealing or avoiding the divided symbolic order in the name of integration, acknowledge its negativity, and stay with the symbolic order. 
which metanarrative is disbelieved, the symbolic order is destroyed, and identical identity is threatened, the subject stands dangerously on shaking ground. Kings in period films from the 2000s are not different from the naked emperor. The collapse of metanarratives announces the disappearance of the foundation of the symbolic order (king). In this era, the king who is summoned on the screen does not know how to define himself as a king. Even if he is the king, there is no such thing as a stable foundation. He screams "I am the king!" but in our eyes, he is merely a "naked emperor." This is the reason the kings in period films from the 2000s continue to be disturbed as they experience identity crises. ${ }^{3} \mathrm{~A}$ narrative with a king who is experiencing an identity crisis is a sign of postmodern society, in which metanarratives have been destroyed-the naked emperor, a sign of the postmodern era where the center of gravity that keeps the balance of the world no longer exists.

\section{The "Enjoy!" Era and the Bearer of the Forbidden}

In the Treacherous, Yim Sung-jae tells his father, Yim Sa-hong, "I have the power to rule over the king. I am the king above king!" Yim Sung-jae only becomes keenly aware of the limitations of his position in society as he begins to desire Tan-hŭi, the "king's woman." Although he is well aware of what would happen to him when he covets the king's possessions, he is unable to control his desire. Yim Sung-jae's desire represents the impetus that drives the narrative of period films from the

3 The position of the disturbed subject was borrowed from Stuart Hall. He argues that the concept of identity in the postmodern era is positioned not only by the fact that the collective identity has been fragmented but also by the fact that such fragmentation and disturbance define an individual as a subject. In other words, disturbances in the postmodern era exist within us. For Stuart Halls' argument, refer to Stuart Hall, "The meaning of New Times," in Stuart Hall, Martin Jacques (ed), New Times: The Changing Face of Politics in the 1990s (London: Lawrence \& Wishart, 1989). 
2000s. Period films from the 2000 s are characteristic in that the narrative is developed by the "desire for the forbidden." At this point, the king's role in the film - whether he is a central or a peripheral character-is secondary. The king is sufficient as the "bearer of the forbidden." If desire lies where there is forbiddance, the ultimate role of the king (or the throne) is to elicit the "desire for the forbidden." On the surface, these narrative characteristics of period films from the 2000s might seem to have resulted from postmodern society, which "forbids taboos," or more specifically, affirms the desire for the forbidden. Now then, we must question why such desires need to be presented against the background of the "era of kings"? In other words, where did the cinematic imagination about the king as the bearer of the forbidden originate?

Let us return to the aforementioned collapse of metanarratives, or the society in which the symbolic order has collapsed. Such society presents us with the gift of the "freedom to choose." However, this freedom is similar to the Trojan horse. Inside the "freedom to choose" is the "desire for violation." Forbiddance is necessary for violation. This is why Zizek argues that a deluge of freedom only arouses the desire for regulations. It can be explained more clearly by the distinction of the law and the super ego. The law is the bearer of the forbidden (oppression) that urges us to renounce jouissance, and the super ego is the voice that "furtively" commands us to "Enjoy!" behind the law. However, in the postmodern society, the relationship between the law and the super ego is reversed. The super ego ("Enjoy!") which should hide behind the law begins to command people out in the front. At this point, the freedom for jouissance turns into a duty. ${ }^{4}$ Obligatory jouissance-when we are required to enjoy

4 I wish to define the Korean society in the present as the "Enjoy!" era. Celebrity athletes say that they want to enjoy the game rather than focusing on winning; singers on stages tell the audience to just enjoy; judges for audition programs on TV decide on the winner by how much the contestants enjoy being on the stage. A society that advises people to enjoy, or the society in which enjoyment has become a duty - this is the society in which we live. 
something - is not enjoyable, as we can tell from our experience.

In the face of the "postmodern paradox," 5 in which the deluge of freedom brought on by the "Enjoy!" era elicits the desire for regulation, period films from the 2000s scream, "Oh, forbiddance! My forbiddance!" just as Yŏnsan in the Treacherous questions Yim Sung-jae, "Do you not know what happens when you covet what belongs to the king?" Korean films today desire to revive the lost jouissance. And the way to do it is by reviving the era of kings, or the era of forbiddance. This is the "imaginative solution" 6 that period films opted for in order to break through the crisis, in which jouissance has disappeared. The struggle to recover the possibility of the lost jouissance by imagining the era of the forbidden in the postmodern era, where jouissance is hindered by unbridled jouissance - this struggle gave birth to period films in the 2000s.

\section{Surface Aestheticization}

Two important aesthetic characteristics of postmodernism are "lack of

5 For the paradox, in which the lack of law universalizes forbiddance, refer to Slavoj Zizek, op. cit., p. 156-159. Slavoj Zizek, Hwansang-ǔi tollimbyǒng (The Plague of Fantasies), (Ingan sarang, 2002), p. 220-228.

6 The "Imaginative Solution" refers to the attitude to resolve social issues imaginatively through hopes and nostalgia. This was inspired by Stuart Hall's concept of "Resistance through Ritual," but I wish to differentiate "imaginative solution" from "resistance through ritual" for an important distinction. The point I emphasize in Hall's concept of "Resistance through Rituals" is the fact that cultural expressions engage in an imaginative relationship with actual conditions in society to magically resolve contradictions in the society. However, I have misgivings about the fact that such magical solutions take on the air of resistance against the dominant culture. Therefore rather than "resistance through rituals," I wish to use "imaginative solution." For "resistance through rituals," refer to Stuart Hall, "Subculture, cultures and class," in Stuart Hall, Tony Jefferson (ed), Resistance through Rituals: Youth Subcultures in Post-war Britain (London: Hutchinson, 1976), pp.47-48. 
depth" and "obsession with the surface." No other genre in the Korean cinema than period films from the 2000s obsesses over the surface as much. The scene in the Treacherous, where unp'yŏng dance, showing off their beauty in a competition to be chosen by the king, is a direct reflection of the trend of period films from the 2000s, which focuses on surficial beauty. Period films from the 2000s attempt to translate historical spaces (including costumes and props) from a modern viewpoint, and as a result, "hybridization" of the present and the past occurs. Therefore historical spaces in these films are decorated and displayed for the sake of beauty and visual pleasure. Although these visual decorations are rooted in historical truth, their purpose does not lie in reflecting history, but rather in exhibiting ornate beauty. History is only a pretext to decorate as much as desired. Wolfgang Welsch defines the aesthetic trend in the economic strategy to sell what could not be sold by wrapping it with beauty as "surface aestheticization." 7 This trend originates from the desire to embellish everyday spaces with aesthetic elements and to make the reality mellifluous through aesthetic ambience.

In this trend, the palace no longer is a taxidermied museum; it is reborn as an aestheticized space. The abundant and rich cinematic atmosphere in period films from the 2000 s is made possible due to the surficially embellished images rather than the narrative. As a result, the palace becomes a place that captures the eyes of the audience, or the place of revived jouissance. Fredric Jameson stated, "the visual is essentially pornographic, which is to say it has its end in rapt, mindless fascination."8

7 Wolfgang Welsch, trans. Shim Hye-ryŏn, Mihak-ŭi kyŏnggye-rŭl nŏmŏsŏ: hyŏndae mihak-üi saeroun sinario, chindan, chŏnmang (Beyond the boundaries of aesthetics: a new scenario, diagnosis, and outlook on modern aesthetics), (Hyangyŏn, 2005), p. 22-26. The nature of surface aestheticization becomes clearer when contrasted against modernist (architecture) aesthetics. Just as the slogan "Ornament is a crime" shows, modernist architecture with geometric designs based on efficiency was better received than ornate architecture with decorations. In this aspect, surface aestheticization, which pursues surficial decoration and exhibition for the sake of beauty and visual pleasure, exists as an antipode to modernist aesthetics. 
His statement sounds like a warning against the essential characteristic of the camera, which can turn the object of its gaze into a "visual fetish." However, using the historical characteristic of the palace as a "hidden space," period films from the 2000s turn the palace into a visual space overflowing with sensuality. Moreover, the inside of the palace have to be blocked off from the gaze of the commoners, and affairs happening in the palace has to be secrets with layer upon layer. However, "the hidden" arouses our voyeuristic desire through the simple fact that it is hidden. This is the reason most period films from the 2000s concentrate on "historical assumptions" or affairs that had been "hidden" from the official history.

In this aspect, the usage of voyeuristic point of view shots that repeatedly appear in period films from the 2000 s is very intriguing. In Forbidden Quest, an eunuch covertly watches the sexual intercourse between the queen and an official; in the Concubine, a kungnyŏ, or a court lady, secretly observes the sexual intercourse between the king and the queen; in a Frozen Flower, the king steals a peek at the sexual intercourse between the queen and her lover. The point of view shots are cinematic expressions, commonly used in love scenes.

Yet, in these films, which are set in the palace - a "place that has to be hidden"-repeated voyeuristic point of view shots are not irrelevant to the historical stance these films take, which attempt to steal a look at the "bare skin of the history that had been hidden beneath a veil." As such, the attempt of these films to rely on sensual pleasure that comes from peeping at the hidden is another struggle to revive the vanished possibility of jouissance. The voyeuristic gaze does not simply peep at a sexual intercourse between a naked man and woman, but rather the pleasure from peeping into the forbidden space. The history that is sensualized in such a way becomes the object of visual pleasure. This is the reason the Korean cinema in the postmodern era has a need for history.

8 Fredric Jameson, trans. Nam In-yŏng, Poi-nŭn kŏs-ŭi narin (Signatures of the Visible), (Hanarae, 2003), p.13. 
